\title{
3 次元流動モデルによる津波防波堤の防護効果に関する数値計算
}

\author{
富田孝史*・柿沼太郎**・島田昭男***
}

巨大津波に対するハード的およびソフト的な防護対策を構築するためには，津波による被害を予め精度良く推定すること が大切である. 本研究では, 多層レベルモデル，3 次元流動モデルおよび 3 次元 VOF モデルから構成される数值モデルを開 発しており，本論文において，数值モデルの妥当性を既存の模型実験結果との比較から検証した。そして，津波防波堤周辺 および背後地における津波の数值計算を行い, 震源から遡上域まで含めた津波の現象が, 本数值モデルにより詳細に把握で きること, また, 防波堤開口部における 3 次元流動が, 堤頭部のみならず堤幹部においても, 構造物の安定性に対して重要 な防波堤前後の水位差に影響を及ほすすことを明らかにした。

\section{1.はじめに}

東海, 東南海, 南海地震等による津波被害を防除・軽 減する対策が緊急的に求められている．特に，巨大津波 の場合には，防潮堤等の防護施設によるハード的な対策 と防災情報や避難対策等のソフト的な対策を有効に連携 させなければならない. 必要な防護施設の強化やソフト 対策を構築するためには，防護施設による防護機能を評 価した上で，防護施設の背後で津波遡上によってどの様 な水位, 流速, 流体力, 浸水域が発生するのかを明らか にする必要がある。

津波の数値計算では, 線形長波理論と非線形長波理論 に基づいた数值モデルを結合させる手法(例えば, 後藤・ 佐藤，1993）が現在よく用いられており，最近では非線 形分散波理論に基づいた数値モデル（岩瀬ら，2002）に より津波の遡上をかなり精緻に計算できるようになって きた.さらに，正村ら（2001）は非静水圧 3 次元モデル と静水圧平面 2 次元モデルを結合したモデルを開発して いる．人口や資産の集積した臨海都市部では，防潮堤等 の防護施設を含めて多くの構造物があり，それら周辺の 津波は 3 次元的な挙動を示すと考えられるので, こう いった現象を考慮した津波計算が大切である.

著者らは，これまでに 3 次元流動モデルを組み込んだ 高潮・津波シミュレータ (STOC：Storm surge and Tsunami simulator in Oceans and Coastal areas）を開 発して, 津波防波堤の開口部における津波の 3 次元流動 や開口部潜堤に作用する津波波圧を計算できることを確 認してきた(柿沼ら，2003)。ここでは，本モデルを浸水 問題に適用できるよう拡張する。そして, 既往の津波模 型実験結果との比較により数值モデルの検証を行ってか ら，これまで十分に検討されていない津波防波堤の堤幹 部の安定性に及ぼす 3 次元流動の影響や，津波防波堤背 後の陸上遡上について検討する.

\footnotetext{
* 正会員 博(工） (独法)港湾空港技術研究所 海洋・水工部 高潮津 波研究室長

** 正会員 博(工）（独法)港湾空港技術研究所 海洋・水工部

*** (株)富士総合研究所産業安全解析センター
}

\section{2. 数値モデルの概要}

本研究で開発してきた数値モデル STOC は，3 次元流 動モデル (STOC-NS) と多層レベルモデル (STOC-ML) によるハイブリッドモデルであり, それぞれのモデル適 用領域を接合させるために，それらの間に接合モデルを 適用する領域を設けた。接続領域は, STOC-ML と STOC-NS をともに適用する領域であり, 例えば, STOCNS の外側に STOC-ML を配置する場合には, 接続領域 の外側が STOC-NS 適用領域の境界, 内側が STOC-ML 適用領域の境界となる。

STOC-NSの基礎方程式は, ポーラスモデル（榊山ら， 1990）を適用した 3 次元の連続式（式（1））と NavierStokes 方程式(式 (2)) である.なお,このモデルでは, 水面位置を鉛直方向に積分した連続式（式（3)）から算 出することとしたので, 哗波のように水面形が鉛直方向 に多価になる場合には適用できない。

$$
\begin{aligned}
& \frac{\partial \gamma_{i} u_{i}}{\partial x_{i}}=0 \\
& \gamma_{v} \frac{\partial u_{i}}{\partial t}+\frac{\partial \gamma_{j} u_{i} u_{j}}{\partial x_{j}}+C_{i}=\frac{\gamma_{v}}{\rho_{0}} \frac{\partial p}{\partial x_{i}} \\
& +\gamma_{v} \frac{\rho-\rho_{0}}{\rho_{0}} g_{i}+\frac{\partial}{\partial x_{j}}\left\{\gamma_{j} v_{e}\left(\frac{\partial u_{i}}{\partial x_{j}}+\frac{\partial v_{j}}{\partial x_{i}}\right)\right\} \\
& \gamma_{z} \frac{\partial \eta}{\partial t}+\frac{\partial}{\partial x} \int_{-h}^{\eta} \gamma_{x} u d z+\frac{\partial}{\partial y} \int_{-h}^{\eta} \gamma_{y} v d z=0
\end{aligned}
$$

ここに, $x_{i}$ はデカルト座標系 $(x, y, z), u_{i}$ は $x_{i}$ 方向の 流速 $(u, v, w), \eta$ は水位変動, $h$ は基準水面からの水 深, $\rho_{0}$ は基準密度, $p$ は圧力, $\gamma_{v}$ は有効体積多孔率(メッ シュ内を占める液相の体積率, $\left.0 \leqq \gamma_{v} \leqq 1\right), \gamma_{i}$ は $x_{i}$ 方向 の有効面透過率 $\left(\gamma_{x}, \gamma_{y}, \gamma_{z}\right.$ : 断面を占める液相の面積率, $\left.0 \leqq \gamma_{i} \leqq 1\right), g_{i}$ は各方向の重力加速度 $(0,0, g), \nu_{e}$ は実 効動粘性係数（動粘性係数と渦動粘性係数の和）である. $C_{i}$ はコリオリ項であり， $x$ および $y$ 方向ではそれぞれ 一 $f_{0} v$ および $f_{0} u$ であり， $f_{0}$ はコリオリのパラメタであ る. 密度 $\rho$ に関しては, 温度および塩分に関する移流・ 拡散方程式を数值的に解き, 得られた温度と塩分を経験 
式（例えば，松梨編，1993）に代入して求めることとし た。これらを基礎方程式として，スタッガードメッシュ で空間を離散化し，リープフロッグ法により時間発展さ せた。

STOC-ML は，鉛直方向を数層に分割し，各層に静水 圧近似を適用したモデルである，圧力を解かないという こと以外はSTOC-NS と同様の計算手法を用いた。

乱流モデルには, SGS 渦動粘性係数のように計算メッ シュの大きさに依存させる.ゼロ方程式モデルの他, 高レ イノルズ数型 $k-\varepsilon 2$ 方程式モデルも採用できるように した（数值流体力学編集委員会編，1995）.

さらに, VOF 法 (沿岸開発技術研究センター, 2001) を拡張した 3 次元 VOF モデル (STOC-VF) も新たに導 入できるようにした。このモデルでは, 自由表面位置の 計算をするために，式（３）の代わりにVOF 関数に関す る移流方程式を解くので, 砕波のように水面形が多価に なる場合にも計算が可能である.

\section{3. 模型実験結果との比較}

\section{（1）津波防波堤に関する模型実験}

谷本ら（1988）が，釜石湾口防波堤を対象とした 3 次 元模型実験（模型縮尺 $1 / 50$ ）を実施しているので，その 結果と比較した。数值計算では, 実験水槽の全体に STOC-NS を適用した。計算格子サイズは, 流れ方向(全 長 $40 \mathrm{~m}$ )では, 開口部潜堤を中心とした前後 $10 \mathrm{~m}$ の範囲 で $25 \mathrm{~cm}$ あるいは $12.5 \mathrm{~cm}$, その両外側で $50 \mathrm{~cm}$ とし, 流れに直交する方向（全長 $20 \mathrm{~m}$ ) では, 全て $25 \mathrm{~cm}$ とし た。鉛直方向には静水面を基準として, $-120,-100$, $-80,-60,-50,-40,-30,-20,-10,-6,-4,-2,0$, $2 ， 4 ， 6 ， 10$ および $20 \mathrm{~cm}$ に計算格子を設定した.

図一 1 は，防波堤開口部中央を通る流れ方向の水位の 空間変化について模型実験結果と数値計算結果を比較し たものである. 模型実験ケースは開口部の平均流速が $0.98 \mathrm{~m} / \mathrm{s}$ および $1.05 \mathrm{~m} / \mathrm{s}$ ののであり, 数值計算では これらに対応させて $1.0 \mathrm{~m} / \mathrm{s}$ とした。

防波堤開口部におけるエネルギー減衰が重要になるの で, 渦動粘性係数を幾つか変えた数值計算を実施した。 水平方向および鉛直方向の渦動粘性係数としては, 定数 として $1.0 \times 10^{-6} \sim 1.0 \times 10^{-2} \mathrm{~m}^{2} / \mathrm{s}$ の範囲で変化させた 場合および SGS 渦動粘性モデル (モデル定数 $\left.C_{s}=0.2\right)$ を使用した場合について行った。なお，定数としての $1.0 \times 10^{-6} \mathrm{~m}^{2} / \mathrm{s}$ は $20^{\circ} \mathrm{C}$ における水の動粘性係数である. 図中の例えば $(-2,-4)$ は, 水平および鉛直方向の渦動 粘性係数の 10 のべき数を示しており, 水平および鉛直渦 動粘性係数がそれぞれ $1.0 \times 10^{-2} \mathrm{~m}^{2} / \mathrm{s}$ および $1.0 \times 10^{-4}$ $\mathrm{m}^{2} / \mathrm{s}$ であることを示している．また，(SGS) および (SGS, F) は，SGS 渦動粘性係数を適用したケースであ

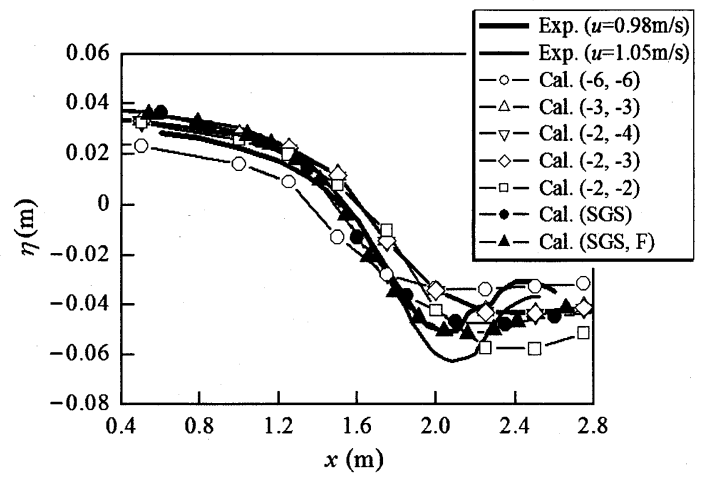

図一1 津波防波堤開口部潜堤周りの水面波形の比較

り，このうち $\mathrm{F}$ の付くものは， $x$ 方向の計算格子サイズ を $25 \mathrm{~cm}$ から $12.5 \mathrm{~cm}$ に細かくしたケースである.

同図によると, 動粘性係数 $1.0 \times 10^{-6} \mathrm{~m}^{2} / \mathrm{s}$ を使った計 算結果は，渦による乱れを考慮できないため，実験結果 と全く一致しない．渦による乱れを考虑した定数の渦動 粘性係数の場合, 開口部沖側（図中 $x<1.6 \mathrm{~m}$ ）の範囲で は, 渦動粘性係数の差異は水位の空間変化に大きな影響 を及ぼさないが, 開口部背後では大きな影響が現れてい る. 鉛直方向渦動粘性係数が小さな $(-3,-3),(-2$, -4）および $(-2,-3)$ では開口部の渦によるエネルギー の低減が十分でなく，水位の低下量が実験に比べると小 さい. 一方, 水平方向扔よび鉛直方向渦動粘性係数を共 に $1.0 \times 10^{-2} \mathrm{~m}^{2} / \mathrm{s}$ としたケースでは, 実駼結果と比較的 よく一致する. 数值モデルにおいて鉛直渦動粘性係数を 大きくしないと実験結果を再現することができないの は，水深 $1.2 \mathrm{~m}$ の開口部に高さ $0.82 \mathrm{~m}$ の潜堤があるた め鉛直方向の渦による乱れの寄与が大きかったためと考 えられる。

また, SGS 渦動粘性係数を使った場合には, 定数とし ての渦動粘性係数よりもさらに実験結果とよく一致する ようになり，細かな計算格子を使うとさらに実験結果に 一致する.ただし, 実験では, $x=2.1 \mathrm{~m}$ から $2.4 \mathrm{~m}$ にか けて水位がー $0.06 \mathrm{~m}$ から $-0.04 \mathrm{~m}$ まで回復している が, 数值計算では水位の回復の程度は弱い. この水位の 回復過程は, $y$ 方向や潜堤上部近傍の $z$ 方向の計算格子 サイズを更に細かくすることにより，実験結果に合うよ うになるのではないかと思われる。

\section{（2）斜面上の津波に関する模型実験}

斜面上の津波について, 鶴谷・中野による断面模型実 験 (谷本ら，1983）と比較する。図一2(a) は, 勾配 $1 / 200$ の斜面上に周期 $40 \mathrm{~s}$, 図中 $\mathrm{H}$ (斜面前面の一様水深部, 静水深 $1 \mathrm{~m})$ に抢ける波形勾配が $1.9 \times 10^{-4}$ 程度の津波 が来襲する場合の実験ケース（参考文献中の図-6.8）を 示しており, 同図 (b) はこれに対応させたSTOC-NSに 


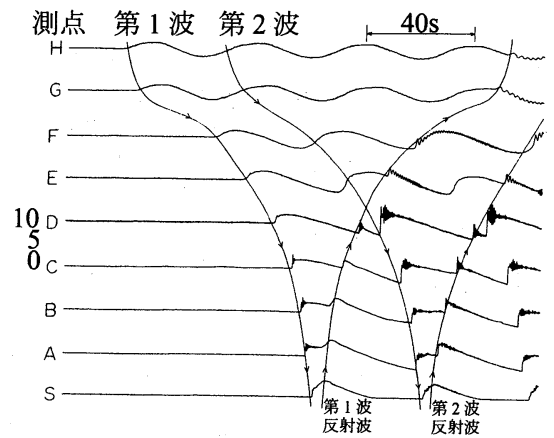

（a）模型実験結果（谷本ら（1983）における図－6.8）

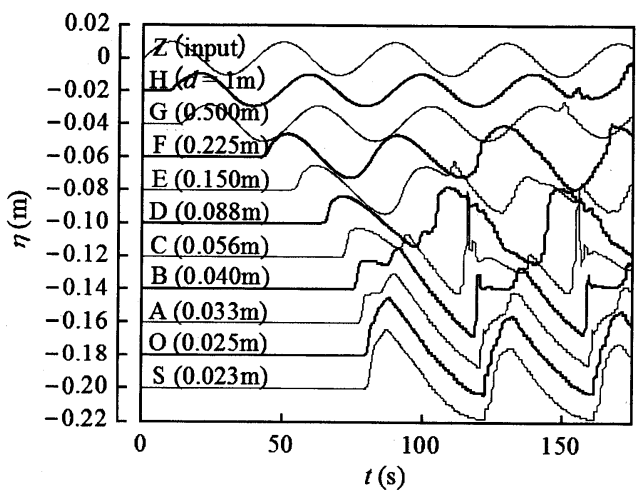

(b) 計算結果

図一2 斜面上の津波波形の比較

よる数値計算結果である. 図中に示した $d$ はその地点に おける水深である。

数值計算では, 計算格子サイズを $\Delta x / L=4 \times 10^{-3}$ 抢よ び $\Delta z / H=0.5$ とした。ここに, $L$ は造波境界における波 長, $H$ は造波波高である.計算結果は, 計算值の地点 Cで は，沖からの津波の第 2 波と岸からの反射波が重合する ときに高い水位上昇量が現れて, 模型実験結果と一致し ていないが，その他の地点においては概ね良好に模型実 験結果を再現することができた，このように，砕波を考 慮することができないSTOC-NS であっても, 模型実験 で出現した斜面上をソリトン分裂して遡上する津波を破 綻せずに概ね良好に計算できた。

\section{4. 津波防波堤の周辺海域への適用}

前報（柿沼ら，2003）と同様に，図一 3 に示す津波防波 堤開口部潜堤を中心とした $1 \mathrm{~km} \times 1 \mathrm{~km}$ の範囲に STOC-NS を適用し, その周囲に単層の STOC-ML を配 置した. 計算格子サイズは, 図に示した全領域で $x$ 方向 (東西方向）および $y$ 方向（南北方向）ともに $12.5 \mathrm{~m}$ で ある. STOC-NS の適用領域では鉛直方向の格子サイズ を適宜変化させ, 自由表面近傍では $1 \mathrm{~m}$ の格子サイズに

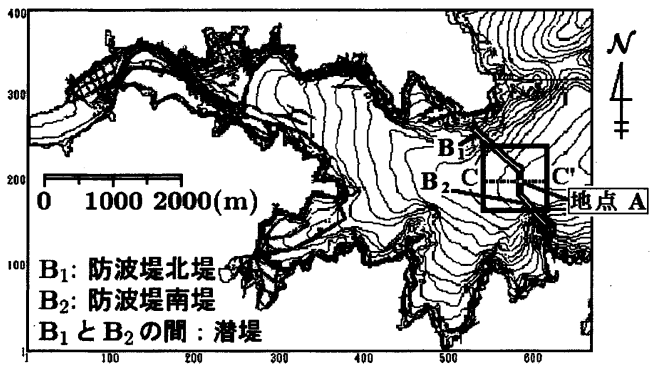

図-3 津波防波堤に関する数值計算領域

した．接続領域は 1 辺 $1 \mathrm{~km}$ 正方形を外縁として 10 メッ シュ内側までの範囲である。全計算領域は, 明治三陸地 震の震源位置を含む領域とし, 明治三陸地震による津波 を断層パラメタから計算した。

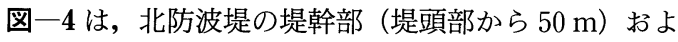
び南防波堤の堤幹部（堤頭部から $80 \mathrm{~m}$ ) における防波堤 の堤外側水位 $\eta_{i}$ と堤内側水位 $\eta_{b}$ の差を示したものであ る. 防波堤の堤幹部では，堤頭部と異なり津波の水位に よる静水圧的な力が支配的となるので，この水位差の評 価が堤体の安定性に重要な影響を及ぼすことになる。数 值計算に使用した水平抢よび鉛直方向の渦動粘性係数 は，それぞれ海水流動計算においてよく用いられる $1.0 \times 10^{2} \mathrm{~m}^{2} / \mathrm{s}$ と $1.0 \times 10^{-2} \mathrm{~m}^{2} / \mathrm{s}$ である. なお, 図には比 較のために，平面 2 次元モデルによる結果を併記してお り，使用した運動量補正係数は後藤・佐藤（1993）によ り釜石湾口防波堤に対して提案されている $f_{D}=0.5$ であ る. 図によると, 押し波時では, 北防波堤においては 3 次元流動の効果はほとんど現れていないが, 南防波堤で は 3 次元流動の効果により平面 2 次元モデルに比べて 1.1 倍の水位差が発生している.一方, 引き波時では, 北 防波堤と南防波堤共に，3 次元流動を考慮した場合にお いて 1.25 倍程度水位差が大きくなっている.これらの差 異は, 開口部における 3 次元流動が防波堤堤頭部だけで なく堤幹部にも影響を及ぼすことを示しているので，堤 幹部における 3 次元流動の影響把握が今後の課題とな る.さらに, 乱流の評価をより精度高く行うことにより 結果は異なることが予想されるので, 乱流モデルの検討 も必要である.

図一5 は，津波防波堤で守られた北側湾奥部における 陸上の津波浸水深を示したものである。この領域に来襲 する津波を（a）と（b）で同一にしているが，(a）の 3 次元計算により得られた浸水域は全体的に狭くなってい る. とくに，埠頭中央部分に津波浸水が発生しない三角 形状の領域が認められるが, これは，この三角形状の領 域の沖側および港内側境界に位置する高さ $3 \mathrm{~m}$ 程度の 壁を津波が越えなかったためである。しかし，この領域 


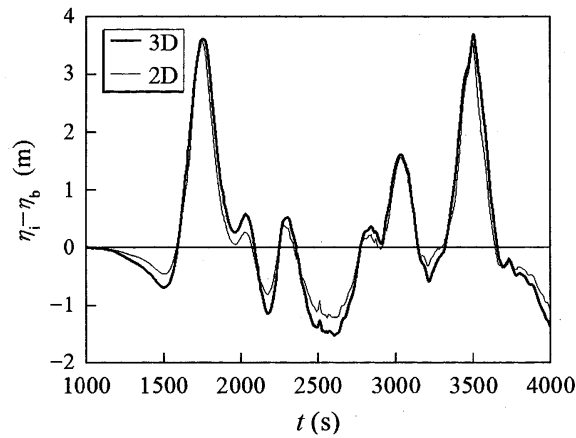

（a）北防波堤の堤幹部（堤頭部から $50 \mathrm{~m}$ )

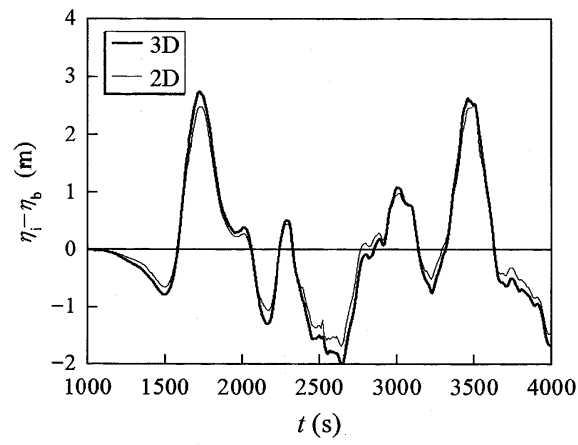

（b）南防波堤の堤幹部（堤頭部から $80 \mathrm{~m}$ )

図-4 津波防波堤の堤幹部前後の津波による水位差

は平面 2 次元計算では浸水している. 海に突き出した埠 頭先端付近の津波遡上水位の時間波形を比較した図一 6 によると, 平面 2 次元計算 (図中 $2 D)$ よりも 3 次元計算 (3D) では津波高さが低くなる傾向にあり，この差異が浸 水するか否かの差を発生させた. どちらが正しいのかを 判断するのは現段階では困難であるが, 少なくともどう いった場所に 3 次元モデルを適用すべきかについて，今 後検討しなければならない.

\section{STOC-VF による津波遡上計算の一例}

防波堤および海岸線に扔ける防潮堤によって守られて いるモデル臨海部にSTOC-VFを適用して津波による 浸水を計算した. 図一7 は, そのときの津波の浸水状況の 時間変化を示したものである.なお, VOF 関数を用いた 津波遡上に関する数值計算には安田ら（2003）もある. 同図（a）で潜堤がある断面の地形は同図（d）に示すよ うであり, 防波堤の高さは $Z=7.0 \mathrm{~m}$ である.津波として は, 防波堤の沖側の海底から $0.5 \mathrm{~m} / \mathrm{s}$ で流入する流れに より, 高さ約 $6.6 \mathrm{~m}$ の津波の来襲を模擬した. 同図 (a) や（b）に見られるように, 防波堤の直背後地では潜堤部 分の直背後に比心゙て津波の到達時刻が若干遅れている が，浸水したときの浸水深の差異はほとんど無い。この

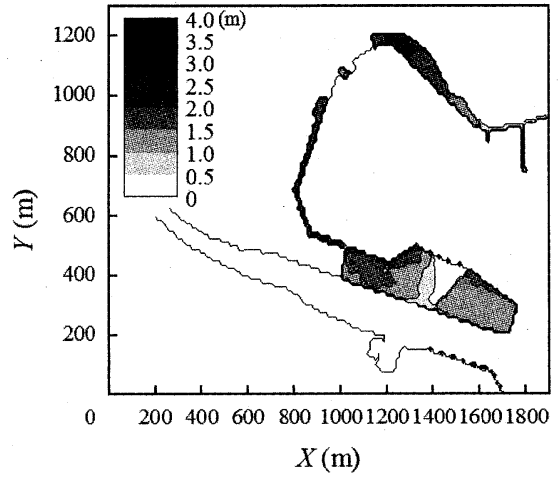

(a) 3 次元計算結果

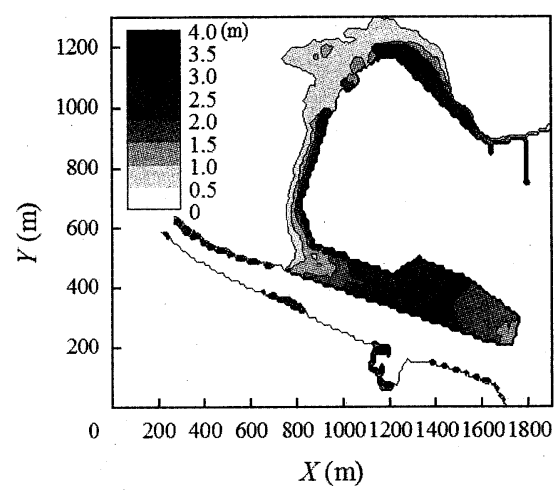

(b) 平面 2 次元計算結果

図一5 湾奥部の最大浸水深

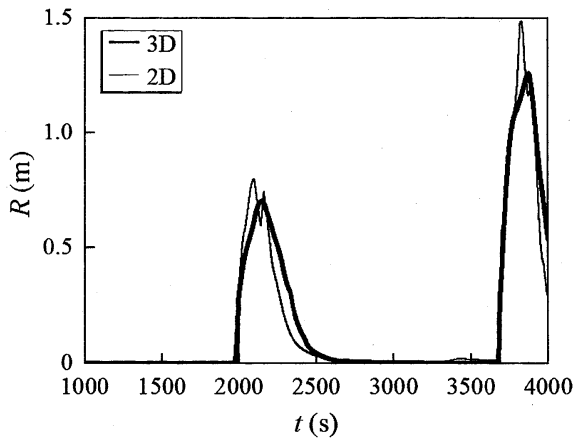

図一6 埠頭先端付近の遡上水位の比較

ように 3 次元 VOF モデルを津波計算に適用することに より，建物周辺の流れの様子を詳細に再現することがで きるようになる．こういった視覚的かつ詳細な計算結果 を示すことで, 津波に対する住民等の理解がより深まり， 迅速かつ的確な避難に役立つものと期待される。

\section{6. おわりに}

本論文では，これまでに開発してきた多層レベルモデ 


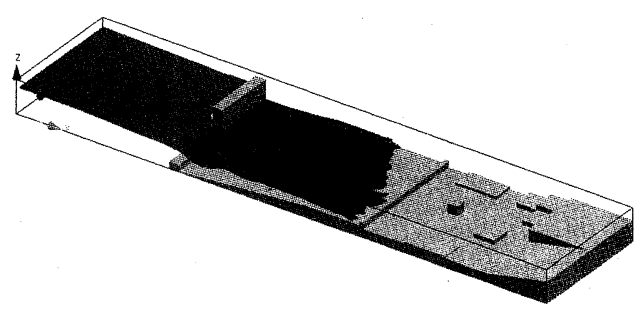

(a) $t=14 \mathrm{~s}$

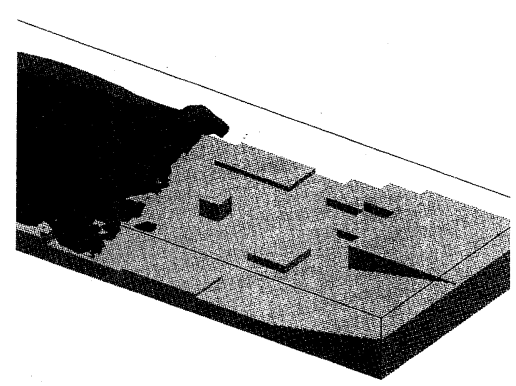

(b) $t=17 \mathrm{~s}$

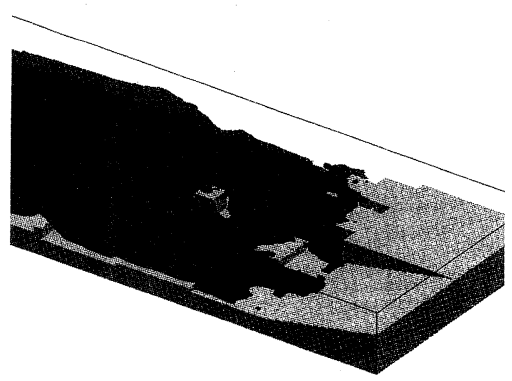

(c) $t=22 \mathrm{~s}$

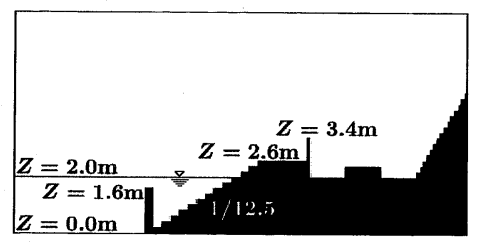

(d) 断面図

図一7 モデル臨海部における STOC-VF の適用

ル, 3 次元流動モデルおよび 3 次元 VOF モデルから構 成される高潮・津波シミュレータ STOC を津波計算に適 用した。 まず，津波防波堤開口部周辺や斜面上の津波に 関する既往の模型実験結果との比較から，3 次元流動モ デルの妥当性や精度を検証した。そして，これまで十分 に検討されていない津波防波堤の堤幹部における津波の 影響について数值計算を行い，防波堤開口部における 3 次元流動が堤幹部にも影響を及ぼすことを明らかにし
た。さらに, 津波防波堤背後に打ける津波の陸上遡上につ いても検討を加え, 震源から遡上域までの津波の現象が 本数値モデルによって詳細に把握できることを示した。

3 次元流動モデルの有効性は構造物周辺に扔ける津波 の現象を精度高く推定することにあり，その精度を上げ るためには乱流モデルの検討を今後十分に行う必要があ る.この問題が解消されると, 3 次元流動モデルと一般 的に用いられる平面 2 次元モデルとの比較から，防波堤 の形状等に依存する運動量損失係数を推定することが可 能になり, この值を用いることで平面 2 次元計算の精度 向上が期待できる. 今後は, 乱流モデルについてさらに 検討を加えるとともに, 津波の 3 次元性を評価すべき箇 所の抽出を行う所存である.

最後に, 本研究の遂行に当たり, 京都大学防災研究所 の特定共同研究 (14P-2)「都市域における氾濫災害危険度 評価法の研究開発」(代表: 高山知司教授)において, 貴 重な意見交換ができました。また，(株)富士総合研究所 の秋山 実氏にはプログラム開発および数值計算の実施 に多大な協力を頂きました.ここに感謝の意を表します。

\section{参 考 文 献}

岩瀬浩之・藤間功司・見上敏文・柴木秀之・後藤智明 (2002)：波 数分散効果を考慮した日本海中部地震津波の遡上計算, 海岸 工学論文集, 第 49 巻, pp. 266-270.

沿岸開発技術研究センター (2001): 数値波動水路の研究・開発 (CADMAS-SURF), 沿岸開発技術ライブラリー, No. 12, 296 p.

柿沼太郎・富田孝史・秋山 実 (2003)：海水流動の 3 次元性を 考慮した高潮・津波の数值計算, 海岸工学論文集, 第 50 巻, pp. 286-290.

後藤智明・佐藤一央 (1993)：三陸沿岸を対象とした津波数値計 算システムの開発, 港湾技術研究所報告, 第 32 巻, 第 2 号, pp. 3-44.

榊山 勉・阿部宣行・鹿島遼一（1990： ポーラスモデルによる 透過性構造物周辺の非線形波動解析, 海岸工学論文集, 第 37 巻, pp. 554-558.

数值流体力学編集委員会編 (1995): 乱流解析, 東京大学出版会, $314 \mathrm{p}$.

谷本勝利・木村克俊・宮崎啓司 (1988)：津波防波堤開口部潜堤 の安定性に関する実験的研究, 港湾技術研究所報告, 第 27 巻, 第 4 号, pp. 93-121.

谷本勝利 ・高山知司・村上和男 - 村田 繁 - 鶴谷広一 ・高橋重雄 ・ 森川雅行・吉本靖俊・中野 晋・平石哲也 (1983)：1983 年 日本海中部地震津波の実態と二・三の考察, 港湾技術研究所 資料, No. 470,299 p.

正村憲史・藤間功司・後藤智明・飯田邦彦・重村利幸 (2001)： 2 次元・ 3 次元ハイブリッドモデルを用いた津波の数值解析, 土木学会論文集, No. 670/II-54, pp. 49-61.

松梨順三郎編 (1993): 環境流体污染, 森北出版, 407 p.

安田誠宏・平石哲也・永瀬恭一・島田昌也 (2003)：流体直接解 析法による臨海部の浸水リスク解析, 海岸工学論文集, 第 50 巻, pp. 301-305. 